\title{
How KANERE Free Press Resists Biopower
}

\author{
MICHELE C. DERAMO
}

\section{Abstract}

How does a free press resist state biopower? This article studies the development and dissemination of KANERE Free Press, a refugee-run news source operating in the Kakuma Refugee Camp, that was founded to create "a more open society in refugee camps and to develop a platform for fair public debate on refugee affairs" (KANERE Vision Statement). The analysis of KANERE and its impact on the political subjectivity of refugees living in Kakuma is framed by Foucault's theory of biopower, the state-sanctioned right to "make live or let die" in its management of human populations. The author demonstrates the force relations between KANERE, its host country of Kenya, and the UNHCR through two ongoing stories covered by KANERE: the broad rejection of the MixMe nutritional supplement and the expressed disdain for the camp's World Refugees Day celebration. Using ethnographic and decolonizing methodologies, the author privileges the voices and perspectives of the KANERE editors and the Kakuma residents they interviewed in order to provide a ground-level view of refugee's lived experiences in Kakuma. As KANERE records refugees' experiences of life in the camp, they construct a narrative community that is simultaneously produced by and resistant to the regulations and control of camp administration and state sovereignty. In doing so, KANERE creates a transgressive space that reaches beyond the confines of the camp.

\section{Résumé}

Par quels moyens peut une presse libre résister au biopouvoir de l'état? Cet article se penche sur le développement et la dissémination de la KANERE Free Press, une source d'actualités gérée par les réfugiés qui opère dans le Kakuma Refugee Camp (camp des réfugiés de Kakuma) fondé dans l'intention de créer "une société plus ouverte dans le camp des réfugiés et d'établir un cadre pour un débat public juste et équitable sur les questions concernant les réfugiés» (extrait de l'énoncé de vision KANERE). Cette analyse de la KANERE Free Press et de son impact sur la subjectivité politique des réfugiés installés à Kakuma s'opère dans le contexte de la théorie de Foucault du biopouvoir, le droit détenu par l'état de "faire vivre ou laisser mourir» dans son administration des populations humaines. L'auteur démontre les relations de force qui existent entre KANERE et son état hôte du Kenya, ainsi que le HCR, par l'entremise de deux instances d'actualités en cours qui ont fait l'objet d'un reportage par KANERE: le rejet généralisé du complément alimentaire MixMe et le mépris manifesté à l'égard des fêtes du camp pour la Journée mondiale des réfugiés. En se servant des méthodologies ethnographiques et de décolonisation, l'auteur place au premier plan les voix et perspectives des rédacteurs de KANERE ainsi que les résidents qui ont participé aux entrevues afin de fournir un aperçu intime des expériences vécues des réfugiés à Kakuma. En rapportant les expériences de la vie des réfugiés internés dans le camp, KANERE développe une communauté liée par le récit qui est à la fois le produit des règlements et du système de contrôle de l'administration du camp et de la souveraineté de l'état, et un élément de résistance à cellesci. KANERE crée ainsi un espace transgressif dont la portée s'étend au-delà des limites du camp.

\section{Introduction}

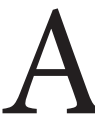
rticle 19 of the Universal Declaration of Human Rights affirms that all persons have the inherent right to freedom of opinion and expression. This right includes freedom to hold opinions without interference and to seek, receive, and impart information and 
ideas through any media and regardless of frontiers. This article raises the question of how the exercise of free opinion and expression occurs for individuals living in conditions of liminality and subject to the regulations of state and international regimes. Specifically, this paper is about the Kakuma News Bulletin (hereafter KANERE), a free press founded and produced by exiled journalists living in the Kakuma Refugee Camp in Turkana County of the northwestern region of Kenya. KANERE's mission to "speak in respect of human rights and the rule of law in order to create a more open society in refugee camps and to develop a platform for fair public debate on refugee affairs" (KANERE Vision Statement) is fulfilled without editorial or financial intervention from the United Nations High Commissioner for Refugees (hereafter UNHCR), the government of Kenya, or any non-governmental organization (NGO) or aid agency associated with the camp. As a result of its decision to operate independent of external intervention, KANERE performs its mission from a position of precarity without a secure funding base and vulnerable to bureaucratic regulations that attempt to control the message being disseminated.

The analysis of KANERE and its impact on the political subjectivity of refugees living in Kakuma is framed by the theory of biopower, defined by Foucault as the state-sanctioned right to "make live or let die" in its management of human populations. ${ }^{1}$ Biopower describes the means by which modern nation-states regulate their subjects through "an explosion of numerous and diverse techniques for achieving the subjugations of bodies and the control of populations." I argue that the refugee camp functions as a technology of power that manages the feeding, housing, and provision of emergency services to populations whose fate as displaced persons is determined by the state. This is especially true in places such as Kenya, where current refugee policy requires that all refugees be contained in camps until a resolution to their status is determined. The effects of encampment is the subjugation of the very individuals it is meant to serve and protect. At Kakuma, residents are wholly dependent upon aid agencies for their survival. They exist in a state of liminality, displaced from their homelands as the result of protracted civil conflicts and segregated from local economies. The level of dependency among Kakuma residents is not only material, but psychic as well. According to Rose Jajj of the Centre for Social Development in Africa, whose research examines the administration of refugee camps, the "efficacy of the social technology in the administration of Kakuma ... manifests itself in refugees' internalization of bureaucratic rules as their own norms and values." 3 Even the production and dissemination of information-whether it be opinion, personal expression, or fact-is subject to editorial oversight by camp administration. Within this context, KANERE'S function as a free press produces a transgressive public sphere that is coterminous with yet also resistant to the operations of biopower.

My approach and analysis are influenced by decolonizing methodologies that privilege the perspectives and lived experiences of the KANERE journalists and the Kakuma residents they interview. Drawing upon the work of Linda Tuhiwai Smith, decolonizing methodologies is defined here as the discursive production of knowledge by "insiders" about themselves for the purpose of dismantling oppression. 4 Thus, at the centre of this investigation are the individuals who produce KANERE, whose commitment to conveying the experiences and opinions of refugees warehoused in one of the most dangerous camps in the world singles them out as troublemakers, placing their lives and their future prospects at even greater risk. Foremost among the KANERE journalists is its founding editor, Qaabata Boru, whose narrative of displacement and insider perspective as a resident of Kakuma is foundational to understanding KANERE's objectives as well as the challenges KANERE confronts in order to fulfill its mission. Boru is, first and foremost, a journalist, therefore his writing and editing are based on the standards of journalism acquired through academic training and professional experience. However, his approach is also influenced by his experience of exile and displacement that occurred as a result of his work as a journalist in Ethiopia. Thus, Boru and his colleagues write not only to convey information, but also to critique the regimes that control their lives and the lives of Kakuma residents - the state of Kenya, the UNHCR, and international aid organizations.

\section{Kenyan Refugee Policy and Kakuma Refugee Camp}

In order to understand the relations of force between KANERE and the agents of biopower, it is important to review the evolution of Kenyan refugee policy after 1990 and the subsequent creation of Kakuma refugee camp. According to Verdirame and Harrell-Bond, Kenya became a party to the 1951 Convention Relating to the Status of Refugees in 1966, and later to the 1967 Protocol, the 1969 oAu Convention, and main human rights treaties. 5 Until 1990, the Kenyan government handled refugee affairs and conducted status determination interviews with UNHCR advisory support. Because Kenya received minimal aid to support refugees, it exercised negligible oversight of asylees entering the country, allowing them to settle freely and find employment on their own. ${ }^{6}$ A small reception centre in Thika provided for destitute asylees while they awaited determination on their status. ${ }^{7}$ Those who were not granted asylum were allowed approximately three months to find another country. The government refrained from erecting obstacles to local integration, 
therefore it was likely that most asylees remained in Nairobi. ${ }^{8}$ Some refugees managed to create secure livelihoods for themselves, despite the broader economic uncertainties facing the country. Others continued to live on the edge of survival, subject to economic insecurity and police harassment, although individual citizens, church leaders, and NGOs would take action on their behalf. 9 Kenyan refugee policy was forced to change after 1990 when more than 400,000 Somalis crossed into the country, fleeing violence and social upheaval, followed by the arrival of 7,00o Sudanese walking boys who were separated from their families when their villages were attacked. The reception centre in Thika, set up to house 350 individuals, was quickly overwhelmed with 8 , ooo refugees. ${ }^{10}$ These inflows prompted the government to appeal for foreign assistance. The prevailing political economy of aid driven by donor nations promoted control and containment of refugees. ${ }^{11}$ Thus, Kenya conceded to encampment as the most efficient way to manage the swelling refugee population. Subsequently, the UNHCR stepped in to establish and operate camps in border areas of the country-Mombasa, Dadaab, Mandera, and Kakumato receive entrants, and contracted with non-governmental organizations to provide specific services to the camps. ${ }^{12}$ The Kakuma camp, located in the Turkana District of northwestern Kenya, was constructed in 1992 to receive the Sudanese and has since expanded to receive refugees from Somalia, Ethiopia, Burundi, the Democratic Republic of Congo, Eritrea, Uganda, and Rwanda.

By $1996-7$, the UNHCR office in Kenya faced budgetary restrictions that led to the elimination of programs. The agency enacted a series of actions that were intended to reduce the refugee population and thereby justify its fiscal decisions. These actions included revalidation exercises (headcounts) to reduce the number of duplicate ration claims, the closure of the Mombasa camp, and the forced relocation of its residents to Dadaab or Kakuma, expecting that this would push some refugees to relocate to other countries or repatriate to their own. ${ }^{13}$ At this time, the UNHCR also assumed responsibility for status determinations.

Agier wrote that "by speaking only of circulations and flows, the management of entrants or the control of encumbrances, the question of the stateless is not just depoliticized, but dehumanized."14 The confinement of the majority of refugees in Kenya to refugee camps resulted in a state of exception, whereby governmental authorities transcended the rule of law guaranteeing non-refoulement and freedom of personhood. What was intended to be a short-term, emergency response to crises in neighbouring countries rapidly resulted in a "transient permanency" that immobilized them in isolated regions of the country, where they were unable to work or participate in public life. ${ }^{15}$ Kakuma and
Dadaab were described in the 2004 World Refugee Survey as "two of the worst examples of the long-term warehousing of refugees": "The camps are rife with human rights abuses: rape, domestic violence, and other crimes were common in the camps; traditional court systems imprisoned refugees for offenses including adultery that were not crimes under Kenyan or international law; and the local population clashed with refugees over resources like firewood."16

Verdirame and Harrell-Bond, in their Rights in Exile, likewise catalogued in great detail how refugees in Kenya routinely faced human rights abuses, primarily by their host government, although "UNHCR, NGOS, and refugee communities played a surprisingly prominent role in many violations."17

According to a March 2015 operational update from the UNHCR and Department of Refugee Affairs, 181,119 persons were registered as living in Kakuma. ${ }^{18}$ Their lives are marked by forced idleness and military control. Under these conditions, refugees become "negative political figures" unable to act on their own behalf, on even the most basic functions. ${ }^{19}$ Yet research has shown that the same conditions that produce refugee bare life can also be the ground for creative resistance and social engagement. Liisa Malkki's work with Hutu refugees in Tanzania showed that the "camp ended up being much more than a device of containment and enclosure; it grew into a locus of continual creative subversion and transformation."2o Likewise, Julie Peteet's engagement with Palestinian refugees in Lebanon revealed that refugee camps, "although spatially bounded units of governance ... are not necessarily spaces of passivity in which refugees wait hopelessly," but were dynamic and frequently contested places where they constructed a sense of meaning, identity, and place. ${ }^{21}$ Refugees-individually and collectively-improvise within the structural and disciplinary forces constraining their lives and, in the process, construct a social life beyond the bare life of the camp. ${ }^{22}$ It is from this ground of force relations that KANERE emerged.

\section{The Creation of KANERE}

Qaabata Boru was a second-year journalism student at Addis Ababa University when he was arrested and jailed for writing a news article that was claimed to have stirred tension at the university. While in detention, he was tortured and indicted as a supporter of a rebel group. Student protests prompted his release after two weeks; however, he continued to receive threats from the Ethiopian government, which has a long record of hostilities toward critical, independent journalists. ${ }^{23}$ The continued threats forced him to flee the country, leaving behind his family and abandoning his education. ${ }^{24}$ He arrived in Kakuma in 2005. 
Boru described his life before exile as "full of happiness, protection with sense of security. It was so lovely-compassionate in sweet family dinner, free talk and everything was real!!" 25 This sense of normalcy diminished when he fled and became a resident of Kakuma:

It was not easy to understand everything within the first few months. Camp life was such a confusing thing and it was like a new university for me; however, I saw and witnessed several incidents that made me critical of UNHCR/NGO's operations, incidents of insecurity and crimes: murders and killings, human rights abuses, sexual exploitation of girls, mistreatment of aid businesses along with other warehousing problems faced by the voiceless camp residents.

From 2006 through 2008-the camp was experiencing increased incidents of attacks and killings. By then I was working as a deputy H/Teacher in Unity Primary School, run by UNHCR / Lutheran World Federation. Some days the pupils did not come to school because people were killed in their community. [At] night or immediately after the sun set, communities patrolled their own demarcated borders as a form of providing security for themselves from attackers who were believed to be members of the host community. ${ }^{26}$

It soon became apparent to Boru that Kakuma's remote location made it possible for insecurities to continue unchecked, and for the authorities responsible for the welfare of the camp residents to avoid accountability for their inaction or perpetration of abuse. ${ }^{27}$ Boru appealed to the form of action that he knew best-that of the written word-working first within the primary school where he had influence:

I formed a journalism club where I taught a group of student in upper primary school about journalism. In a very simple way, the lessons continued periodically, by imparting them to understand "What is news?" In a few weeks the pupils were able to write down "news" happening within their communities and because school is a community where student are coming from all different parts of the camp, I was able to accommodate a lot of news/information happening around the camp. No sooner had I started incorporating the journalism club when several other school teachers joined. I started teaching and held periodic discussions as a way forward following the ongoing insecurity and killings. Sadly, because refugees have no capacity, we couldn't do any publication until I formed KANERE with a group of nine volunteers, of which seven were refugee teachers in the mid-2008. ${ }^{28}$

Boru and the others leveraged the project with the support of an American Fulbright scholar working in Kakuma, Bethany Ojalheto, who used financial resources from her research grant to launch the initiative. With its launch, KANERE became the first fully independent refugeerun news source of its kind to emerge from a refugee camp, using a WordPress blog platform that enabled it to reach international audiences. ${ }^{29}$

The first issue, posted on 22 December 2008, received thousands of hits from viewers worldwide. A limited number of print copies were available at tea shops and kiosks around the camp.

KANERE's goals were twofold. First, it aimed to represent refugee voices in the camp, providing an avenue through which refugees at Kakuma could interact with and speak directly to the outside world, NGOs, and the camp's governing bodies. In doing so, KANERE could achieve its second goal, which was to expose abuses of power, violations of human rights, and exploitation connected with the distribution of food aid, and the negative impact of certain UNHCR policies in Kakuma. ${ }^{30}$ KANERE's reporting categories included arts, business and development, community and culture, and Kakuma Town (among others). Boru was most interested in stories on human rights, crime and insecurity, corruption, and abuse:

I think these stories have a lot of significance because the camp residents have fallen victim of the story topics I have mentioned here above. They need legal and durable redress to their fates! By exposing and informing the camp residents about whatever is happening within the camp and their surrounds, they feel a sense of protection since the first-hand account of inhumane treatments or crimes are published. At the same time, the camp governing authority is held accountable for the same repression, violations of human rights and other forms of abuse on the beneficiaries of food aid. $3^{1}$

\section{The Case of MixMe}

A topic that generated significant discussion across several publications of KANERE was the distribution of MixMe, administered by the World Food Programme. MixMe is a micronutrient powder produced and donated by DSM, a global science-based company based in the Netherlands that is active in health, nutrition, and materials. Product distribution was in response to the high levels of anemia and micronutrient deficiencies found in refugee camps as a result of insufficient food rations. ${ }^{32}$ The MixMe packets were distributed with the monthly food rations, with each beneficiary receiving a box of thirty one-gram sachets. The contents of the sachet were to be sprinkled over the food prepared in the home just before consumption. The intended outcome was to significantly reduce the prevalence of irondeficiency among Kakuma residents.

Despite its ease of use, along with an extensive communications campaign employing film, pamphlets, and plays to 
promote proper use of MixMe, the product was not wellreceived by residents. ${ }^{33}$ Foremost among the complaints raised by residents was why an investment was made in what appeared to be a non-food product rather than local food production. ${ }^{34}$ KANERE staff collected residents' opinions of MixMe and posted their responses verbatim in the Community Talking Points section of the March-April 2009 issue of KANERE:

It's okay, but vitamins are also found in meat, vegetables, etc. Why couldn't WFP supply local food containing these vitamins and minerals? (Anne, Somalia)

It makes people have diarrhea and you know this place is too hot and if you don't get medical attention fast, then you can easily die due to dehydration. Why can't UNHCR do away with Mix Me and instead bring enough water to the people? (Zarah, Somalia)

When consumed, Mix Me increases the appetite and people develop a state of eating too much. While wFP offers little quantity calculated for only 15 days, we've been finding ourselves in condition of food stock out before the expected time-four days before reaching the $15^{\text {th }}$ day. (Bisengo, Congo)

When I first took Mix Me I experienced some stomach disorder and I became very weak. People fear the sign on the sachet of Mix Me. They think it is an animal and so they think Mix Me is for animals and not people to consume. (Student, Jebel Mara Primary School)

It is good and we like it. It should always be given out but some people have to be made aware of it because many people have misunderstood it. (Mark, Sudan)

The powdery appearance of MixMe, combined with the fact that its distribution was limited to refugee camps, raised additional concerns about the integrity of the product. Individuals who spoke to KANERE reporters asked a variety of questions, ranging from the content of the ingredients and whether they would conflict with religious dietary restrictions, to the protocol and decisionmaking behind the allocation of MixMe to Kakuma refugeesand not to Dadaab refugees, or consumers at local markets and shops, or among aid staff. Specifically, residents wanted to know if MixMe was a product trial, and if they were the "guinea pigs" for testing the effectiveness of the product. These questions reflected a heightened sensitivity among residents to the vulnerability of their situation: "The way we see Mix Me as refugees seems to be having a secret behind it that is not yet clear, but transparency will still come out. Can WFP change this Mix Me into locally available or locally produced food rather than bringing externally produced chemicals that are harmful to refugees, who are used as laboratory animals for someone's university research?” (Anonymous, Congo)

The residents' perception of MixMe as a chemical showed as well the proliferation of rumours surrounding the product rollout. The rumours, which included speculations that MixMe was a family-planning drug, demonstrated the kind of suspicions harboured by the refugees toward aid efforts: "People don't want this stuff, as it has created many different perceptions among the refugees ... It also has no country where it was manufactured, and expiration date is not visible clearly. If it is good for human consumption, then even Kenyans should be able to get it or buy it in the shops, but it is not in shops. Why?" (Jebel Mara Primary School student)

The refugees' lack of choice in receiving a product perceived as exotic in a context where they were already denied choice generated fear and mistrust. According to Simon Turner's research in Lukole camp (Tanzania), rumours functioned to impose order in conditions of insecurity, especially in relation to "big actors" and the "big nations." 35 Other researchers have likewise noted that the circulation of rumour represents a form of collective resistance and "call to action" deployed by groups in ambiguous situations attempting to negotiate their circumstances. ${ }^{36}$ Similarly, the discourse of suspicion around MixMe reflected the anxieties of Kakuma refugees in relation to the regimes controlling their bodily lives. 37

KANERE sought to address the questions raised by refugees by approaching World Food Programme officials in the camp for answers. Some of the questions pertaining to nutritional content were publicly available, and KANERE responded with the information in their articles on the MixMe topic. ${ }^{8}$ However, KANERE was unable to secure face-to-face interviews. According to Boru, some officials claimed to be too busy to meet. Others, such as Lourdes Ibarra, refused a meeting based on KANERE's independent status. She indicated that the organization would not provide information to KANERE until the free press was registered as a community-based organization (generally recognized in Kenya as self-help groups). She gave no explanation for why Сво status was required in order for an interview to occur. Yet the decision by the organization to distance themselves from the concerns of the residents reinforced the suspicions circulating about the product.

KANERE's interaction with the World Food Programme demonstrated the kind of unresponsiveness many refugees encountered when attempting to communicate their concerns to camp authorities and humanitarian organizations. Jajj discovered that refugees were expected to negotiate the camp hierarchy through community representatives, who conveyed their concerns to authorities. However, the

(C) Michelle C. Deramo, 2016. This open-access work is licensed under a Creative Commons Attribution-NonCommercial 4.0 International License, which permits use, reproduction and distribution in any medium for non-commercial purposes, provided the original author(s) are credited and the original publication in Refuge: Canada's Journal on Refugees is cited. 
hierarchy functioned to protect the camp bureaucracy, reinforcing "the control and maintenance of social distance between camp administration and aid agencies on the one hand and refugees on the other."39

The MixMe controversy illustrates refugee resistance to biopower. Clearly, the residents resisted being viewed as undifferentiated bodies available for experimentation. They demonstrated their resistance through a 70 per cent refusal of the product, resulting in MixMe sachets being littered across the camp..$^{\circ}$ Despite the widespread rejection of the MixMe product, a joint report on the use of the micronutrient in the Kakuma Refugee Camp, prepared by the UNHCR, the World Food Programme, and DSM stated, "An initial trial with MNP showed high acceptability by mothers who acknowledged improvement in the health of their children, saying that they were looking healthy, playing more and had an increased appetite." ${ }^{\prime 1}$ Ironically, the waste of MixMe sachets created a new employment opportunity for refugees who were hired to collect the discarded sachets.

A DSM designee on a fact-finding mission at Kakuma camp in 2009 observed the waste of the MixMe product. In a blog maintained for friends and family, the designee expressed her astonishment at the refugees' rejection of the product: "Can you imagine, refugees, I repeat, refugees, who have basically nothing, going to the food distribution standing in line to pick up their ration of food, and then just leaving the boxes of Mix Me there." The designee stated that it hurt her to see the sachets lying around on the ground all over the camp because she was "so convinced that it is good for them, and I watch them struggle to survive even, and for a short moment I felt like they do not want to accept our help." 42

Even as she grappled with the recognition of refugees' concerns, the subtext of the MixMe designee was clear: the refugees needed to be convinced that the product was something they should use. The efficient management of refugee health and well-being had to be regulated through the deployment of a biotechnology that reduced the frequency of serious medical issues without changing the actual conditions of the camp. The designee's astonishment that the act of refusal was perpetrated by refugees ("can you imagine refugees, I repeat, refugees who have basically nothing") reinforced a bio-political view that regarded the vulnerable as bodies stripped of political standing or citizenship rights.

The discourse of suspicion characterizing the collective response to MixMe provided valuable insight into the critical relations between Kakuma refugees and the governing agencies that managed the camp. As a case study of resistance within a framework of biopower, the MixMe controversy demonstrated the enactment of agency that disrupted existing relations. Agamben wrote that "humanitarian organizations ... can only grasp human life in the figure of bare or sacred life, and therefore, despite themselves, maintain a secret solidarity with the very powers they set out to fight." 43 Yet the MixMe controversy demonstrated a push back to the sovereignty of state and aid over the refugees' natural lives.

\section{A Transgressive Sphere}

KANERE played an important role in the MixMe controversy by constructing a narrative of resistance that countered the public relations of UNHCR and its subcontractors. As a free press, KANERE provided a space for the production of a public sphere that transgressed the restrictive environment of the refugee camp. Within Kakuma, KANERE gives refugees a platform for speaking directly to various publics, including the aid agencies, about their experiences. Additionally, KANERE contributed to a body politic that transcended national affiliations yet built upon a common identity marked by displacement, insecurity, confinement, and the longing for resolution. "Only a community of existence, based on shared experience and lived situation, can then unite these anonymous crowds in a history made up of violent disruptions, then an administrative category of identity ('refugees,' etc.), and finally a special security and humanitarian treatment. Confined in spaces that are out-places, they see their political existence depends no longer (or not only) on their origins, but on local contexts of identification." 44 KANERE's mission as a free press not only informed and reported, but also countered what Boru described as the monopoly of information enjoyed by humanitarian organizations that largely controlled access to and information about refugee camps. "It is here that collective actions undertaken ... acquire their political meaning, when the occupants of the camps intervene on the terrain that is allocated to them, to demand social rights attaching to their present condition." 45

KANERE'S representation of the refugee camp exposed realities that were typically hidden in the efficient reports of the UNHCR and their NGO subcontractors. According to Verdirame and Harrell-Bond, donor nations and the international community have typically relied upon UNHCR and NGO reports, without giving balanced consideration to the reports of journalists, activists, academic researchers, or the refugees themselves. ${ }^{46}$ Consequently, information circulated about refugee lives and camp conditions was conveyed through the orderly compilation of statistics and influenced by concerns of "image management" and "the impulse to insert a utopian description" over dystopian realities. 47 Similarly, occasions such as World Refugee Day were spectacles that featured speech-making by dignitaries and cultural pageantry, with refugees wearing traditional clothing 
and performing songs and dances from their countries. KANERE'S coverage of World Refugee Day highlighted the indignities of the event that required most refugees to walk up to five kilometres to participate, and then stand in the hot sun to watch, while humanitarian NGOs were seated in the shade with cold refreshments. ${ }^{48}$ As the comments from the KANERE July 2012 Community Talking Points show, the refugees interviewed generally did not share the celebratory spirit of the day: 49

I see no meaning of this day. I have lived here for 6 years with no recognition from both UNHCR and Kenya government. My desire is to go back home when peace prevail in my homeland. (Wechtour, Ethiopian Nuer leader)

This day makes me feel very sad; I am a voluntary prisoner in Kakuma. I can't move freely. I don't see any reason for cheering the day. We should rather preach peace to prevail in the world. Everything is corrupted here, let the UNHCR think right and give us quicker durable solution. (Elros, Ethiopia)

Refugee Day should be commemorated in a special way by giving refugees special gifts or special food ration during the distribution cycle rather than inviting them to dance, I hate that practice. (Ingabine Rose, Congolese)

Being a refugee is bad. You are deprived of most of your rights and freedom. I don't see the purpose of music and dances to make UNHCR and NGOs pleased yet there's no recognition in it. (Rukunda Jean, Rwanda)

Intriguingly, one of the comments posted to the July 2012 World Refugee Day article on the KANERE site was from an Eastern European refugee who signed off as "Victim of the UNHCR": "Being a refugee is a very hard task because of the Refugee's protector-the UNHCR. The UNHCR is destroying me in Ukraine for more than 8 years. I am half abnormal now; because of the UNHCR, my life has changed in a nightmare. Why has the world society has found such a corrupted system that affect people to such extent?"

\section{An Ethic of Risk}

As indicated earlier, the KANERE editorial team was not the first effort to operate a refugee press. From 1993 to 2005, the United Nations ran the Kakuma News Bulletin (KANEBU), which functioned as a newsletter to share information about events occurring throughout the camp. While KANEBU engaged refugee journalists in writing articles for the newsletter, the local UNHCR unit retained editorial control of what was actually published. KANERE set out from the beginning to produce a news source that was different from KANEBU.
First, KANERE would operate independent of UNHCR authority so that it could fulfill its critical purpose rather than function as a public relations tool for the UNHCR. Second, KANERE would use a WordPress blog on the Internet as its media source, thereby reaching beyond the geographic isolation of the Kakuma Camp to establish a borderless format with the potential to reach a global audience.

KANERE'S decision to maintain itself as a free press had grave risks. Soon after its initial publication in December 2008, objections were raised by the UNHCR about its lack of participation, citing concerns over confidentiality, protection of identities of people living in the camp, and ethical standards of reporting. In response, Boru and his colleagues stopped providing article bylines and using the full names of residents, and removed two sensitive articles. Even with its critical mission, KANERE intended to work cooperatively with the UNHCR and aid agencies: "Kanere staff always approach NGO officials for citations for the stories they work on but since UNHCR and its sister partners have jointly illcommunicated against Kanere because we denied UNHCR censorship, there has been no good relationships since its inception. However, Kanere journalist do always approach the humanitarian offices for official comments. When they fail to cooperate, Kanere officials record all the attempts made towards balanced reporting. And yet [UNHCR/NGOs] keep on violating their own policy by refusing to speak with press!"5o

A difficulty KANERE faced in advancing its work was noncooperation or non-response by UNHCR officials, who used their bureaucratic influence to block efforts. ${ }^{51}$ According to an article prepared for the Society for International Development Forum, Olajheto reported that KANERE received a letter from the UNHCR head of suboffice, Mohamed Qassim, stating that the UNHCR "cannot support the pure independence" of a free press that receives the support of "relief funds." He further stated that KANERE did not demonstrate how it added value to the refugee program, therefore support would not be forthcoming until the UNHCR was convinced that the news source served the interest of the camp. Boru responded, "I will not like at any point to collaborate with a UNHCR who [is going to] restrict my work. I wish to work with a free mind, with a full consciousness, without restrictions of what to do and don't, however there are no written documents from UNHCR, but only verbal alerts."52

Other challenges KANERE faced were more overtphysical attacks, verbal threats, theft of equipment, and libellous charges, usually from other refugees who feared that associating with KANERE would jeopardize their resettlement chances. This fear was not wholly unfounded. On several occasions, refugee journalists were interrogated about their involvement with KANERE by protection staff, 
and one was warned to "keep his distance" because involvement in activities that "UNHCR does not like" could put his incentive job at risk. 53 As a consequence of these security threats, the KANERE team dropped from its initial twenty reporters to fifteen and then to its current number of seven active journalists. 54

Articles in Pambazuka News covered a series of incidents in which KANERE was targeted: its registration papers for community-based organization status were confiscated;55 Boru was assaulted, his home vandalized and set on fire, ${ }^{56}$ and his requests for legal protection were ignored. 57 Ojalehito, who collaborated in the launch of KANERE, was told that her work on KANERE was not relevant to her research and therefore she could lose her housing through the Lutheran World Federation..$^{8}$ KANERE journalists regarded these threats as a direct challenge to refugee voice. "Refugee journalists fear opposing the UNHCR, but their desire to struggle for a free press is stronger." 59

KANERE made modest headway in its negotiations with the UNHCR after Dr. Ekuru Aukot, an international human rights lawyer with Kituo Cha Sheria, visited Kakuma and wrote an editorial responding to the question of whether refugees in Kenya had the right to a free press. Aukot's article appealed to ratified legal documents, including the Refugees Act of 2006 and the Constitution of Kenya, to clarify that refugees enjoyed the right to freedom of expression through a free press, provided they followed the ethical standards for journalism. He wrote,

A free press particularly is often interpreted differently depending on what interests are at stake, and on what the free press is exposing or about to expose. States may restrict this right in the excuse of national security. Other authorities such as humanitarian agencies may restrict its enjoyment owing to the fact that to allow refugees, for example, to exercise this right fully may cause embarrassment and would open a series of criticism ... No one should see KANERE as threatening, for example, the security of Kenya, for that is often what typical bureaucrats would argue. There are more worrying and pressing things in Kenya at the moment than to worry about the freedom of individuals to speak out, whether exercised by refugees or Kenyans. ${ }^{60}$

In addition to offering valuable legal support to the legitimacy of KANERE's work, Aukot also exposed the fallacies behind the security arguments upon which the Kenyan government and the UNHCR based their opposition, stating decisively that inhibiting the right to a free press was in direct violation of the Kenyan Constitution. In response to Aukot's editorial on behalf of KANERE, the local UNHCR unit agreed to provide the letter of support needed by KANERE to proceed with its application for Сво recognition. But its support remained conditional on its involvement, arguing that a free press couldn't be purely independent if it was receiving relief funds. KANERE refused these conditions.

During the spring of 2013, the Refugee Newsletter was released in Kakuma. Ostensibly, the newsletter was written and published by refugee youth in a journalism program sponsored by Film Aid. The six-page document was full colour with professional layout, and acknowledged support from the United States Bureau of Population, Refugees, and Migration. The lead article headlined "A New Dawn for Journalism in Kakuma," claiming that the refugee community now had a platform to tell their stories. There was no recognition of KANERE's work. In Boru's opinion, the newsletter was a "countermeasure to oppose Kanere and mitigate the effect of media by contrary action, which is intended to compete with Kanere." ${ }^{\prime \prime}$ Boru also worried that the FilmAid newsletter would confuse international readers who searched for the Kakuma refugee newsletter and found the Refugee Newsletter instead. Boru wrote a public response in the August 2013 publication of KANERE, entitled "New NGO Run-Newsletter Enhances News Access in Kakuma." While the article assumed a conciliatory tone, welcoming the effort and emphasizing the value of multiple sources of news, it drew a sharp distinction between the purposes of each: "According to those of us here at KANERE, the more new voices that emerge, the better that it will shape media environment. There's room for both the NGO-run and a refugee-run newsletter because each media outlet has a different purpose and function ... Going forward, what kind of journalism do we hope is practiced in Kakuma? Journalism that serves democracy and is genuinely interested in exposing issues of public importance would be the kind of the journalism that deserves protection."62

By continually referencing the Refugee Newsletter as the NGO-run newsletter, Boru resisted the claim that the newsletter represented authentic refugee voice, thereby speaking back to any insidious measures that may have threatened erasure of refugee critique.

As of this writing, KANERE continues to function, although precariously. Despite its resource difficulties and its continued problems with camp authorities, KANERE has gained traction. Internally, KANERE has growing support among community leaders within the camp who participate in the circulation of news and information to be included in KANERE reporting. KANERE has also gained an ever-expanding coalition of supporters worldwide. According to the Humanitarian Futures Programme blog, KANERE "is an absolutely fantastic example of citizen journalism, empowered by the web, completely changing the game of humanitarian business," with the potential to catalyze "the next stage of growth for the aid industry." 63 The Refugee Research Network translates KANERE into Japanese. 
Alternative news sources such as Pambazuka News (multiple issues), Society for International Development Forum (October 2, 2009), McGill Daily (3 November 2009), and Forced Migration Review (August 2012) have featured KANERE. Boru was interviewed for a short video by the Commission to Protect Journalists on exiled East African journalists who continue to work in communications outside of their countries. A North American photographer, Dustin Barter, launched a crowd-funding campaign on Indiegogo to purchase laptops and construct a fully equipped, solar-powered office. A group of international supporters of KANERE, which includes the author, reopened the campaign in the spring 2016. ${ }^{64}$ In November 2013, KANERE announced that it obtained its registration status as a national non-governmental organization in Kenya. It strongly welcomes further collaboration from all government departments within Turkana County, the Department of Refugee Affairs, the UNHCR head of suboffice, and other humanitarian agencies in Kakuma. KANERE's global reach gives power to the narrative of the political refugee subject. This narrative is formed discursively from the stories, poems, opinions, interviews, photographs, cartoons, and news collected from districts of the Kakuma camp. Likewise, the story continues to be told in conversation with its global audiences of human rights advocates, resettled refugees, and other communities of solidarity.

\section{Conclusion: Does KANERE Make a Difference?}

Does KANERE make a difference? Boru believes that KANERE'S advocacy for refugee rights has prompted improvements in refugee services, including installation of solar lamps in the camp and the deployment of more police to patrol the camp following reports on security problems. Also, in response to KANERE's reports of inadequate attention to refugee complaints, the UNHCR established field posts throughout the camp so that refugees can speak directly to UNHCR officials. ${ }^{65}$

KANERE also contributes to educational and social development through its journalism training for youth. Similarly, working journalists are able to continue their craft, even though they do so without compensation. Finally, KANERE's work has helped to promote social cohesion among residents through information sharing and awareness of current issues and concerns.

But is asking about material impact the right question? If success is determined by how quickly or effectively KANERE transforms policies of encampment or the operations of Kakuma camp, then its efforts may be perceived as inconsequential. The fact that KANERE survived and has gained an international audience, despite the bureaucratic, physical, and economic threats it has faced, is remarkable. Within the framework of biopower, the actualization of dissent disrupts efficient management and needs to be neutralized. KANERE'S persistence produces a narrative of the politicized refugee subject. Through it we witness a relation of force grounded in an ethic of risk whereby individuals act despite the odds that are against them. ${ }^{66}$ KANERE journalists write because they must, because doing so exercises and creates another sort of power, one that is based in the dangerous memories of suffering and loss. From these memories "a critique of existing institutions and ideologies that blur the recognition and denunciation of injustice" is given voice. ${ }^{67}$

Michele C. Deramo is director of Diversity Education and Initiatives and a doctoral candidate in social and cultural theory at Virginia Tech. The author may be contacted at deramo@vt.edu.

\section{Notes}

1 Michel Foucault, The History of Sexuality: An Introduction, vol. 1 (New York: Vintage, 1978).

2 Ibid., 140.

3 Rose Jajj, "Social Technology and Refugee Encampment in Kenya," Journal of Refugee Studies 25, no. 2 (2011): 233.

4 L. Tuhiwai Smith, Decolonizing Methodologies (New York: Zed Books, 2012).

5 Guglielmo Verdirame and Barbara Harrell-Bond, Rights in Exile: Janus-Faced Humanitarianism (New York: Berghan Books, 2005), 28.

6 Ibid., 31.

7 Ibid.

8 Ibid., 32.

9 Ibid.

10 Ibid., 33 .

11 Ibid., 278.

12 Ibid., 33 .

3 Ibid., 34-5.

14 Michel Agier, Managing the Undesireables: Refugee Camps and Humanitarian Government, trans. David Fernbach (Malden, MA: Polity, 2011), 12.

15 Bulent Diken, "From Refugee Camps to Gated Communities: Biopolitics and the End of the City," Citizenship Studies 8, no. 1 (2004): 94.

16 Merrill Smith, "Warehousing Refugees: A Denial of Rights, a Waste of Humanity," World Refugee Survey, 2004.

17 Verdirame and Harrell-Bond, Rights in Exile, 120.

18 Data from the Kakuma Operational Update, 13-19 March, 2015, UNHCR.

19 Agier, Managing the Undesirables, 18. 
20 Liisa H. Malkki, Purity and Exile, Violence, Memory, and National Cosmology among Hutu Refugees in Tanzania (Chicago: University of Chicago Press, 1995), 36-7.

21 Julie Peteet, Landscape of Hope and Despair: Palestinian Refugee Camps (Philadelphia: University of Pennsylvania Press, 2005).

22 Bram J. Jansen, “Two Decades of Ordering Refugees: The Development of Institutional Multiplicity in Kenya's Kakuma Refugee Camp," in Disasater, Conflict and Society in Crises: Everyday Politics of Crisis Response, ed. Dorothea Hilhorst, 114-31. (New York: Routledge, 2013).

23 According to data collected by the Committee to Protect Journalists, Ethiopia has driven more journalists into exile than any country in the world: seventy-nine since 2001. See Committee to Protect Journalists, http:// www.cpj.org.

24 Details of Boru's life before arriving in Kakuma were drawn from email communications as well as an interview by Andrew McGregor. See "Keeping the News Alive from Outside Ethiopia: Andrew McGregor Interviews Qaabata Boru," Provocations: A Special Series on Freedom of Expression, Los Angeles Review of Books, 24 October 2013.

25 Email correspondence, 15 April 2013.

26 Ibid.

27 Boru links Kakuma's remote location to the prevalence of human rights abuses and the need for a news source to expose these abuses. He cites several reports, including the video Journalists in Exile: Crisis in East Africa, produced by the Committee to Protect Journalists, 19 June 2012, https://www.cpj.org/blog/2012/o6/videojournalists-in-exile.php, and the KANERE entry in the African News Innovation Challenge, summer 2012.

28 Email correspondence, 15 April 2013.

29 Other camps had refugee newsletters, but they typically operated with the support and oversight of NGOs to share news internally. According to Barbara HarrellBond, refugees have produced their own news sources in every camp she visited; however, these efforts were crushed by camp administration (informal conversation March 2014).

30 Editorial Staff, "KAnere: A Refugee Run Free Press in Kakuma," Forced Migration Review 40 (2012), http://www .fmreview.org/en/young-and-out-of-place/kanere.pdf.

31 Email correspondence, 15 April 2013.

32 The International Rescue Committee and UNHCR conducted a nutrition survey at Kakuma refugee camp in 2007 and discovered that 86.7 per cent of the children and 40.6 per cent of the women were anemic. The survey is referenced in Micronutrient Powder (MixMe ${ }^{\mathrm{TM}}$ )
Use in Kakuma Refugee Camp in Kenya (Africa) 1, no. 3 (May 2009), produced by the World Food Programme, DSM, and the UNHCR.

33 Editorial Staff, "MixMe Nutritional Supplement Raises Questions," Kakuma News Reflector 1, nos. 4-5 (March-April 2009), http://kanere.org/2009/05/12/ mixme-nutritional-supplement-raises-questions/.

34 In fact, micronutrient powders such as MixMe are food-based rather than medicinal in origin.

35 Simon Turner, "Under the Gaze of the 'Big Nations': Refugees, Rumours and the International Community in Tanzania," African Affairs 103, no. 441 (2004): 238.

36 Jun Liu, "Rumor, Mobile Phone, and Resistance in Contemporary China," paper presented at "Media in Transition 8” conference, 3 May 2013, MIT, https://lup.lub.lu.se/ search/publication/3768446.

37 While Kakuma residents questioned why they were selected to receive MixMe, local Turkana residents who were queried asked why they were not able to access the product since their nutritional needs and health issues were the same as the refugees': "Local people have not been given or benefited from Mix Me" (Dorcas Ewoi, Turkana), "Community Talking Points: MixMe," Kakuma News Reflector 1, nos. 4-5 (March-April 2009), http:// kanere.org/2009/05/12/community-talking-point-mixme/.

38 Editorial Staff, "World Food Programme Kicks Off and Mix-Me Nutritional Supplement Survey," Kanere News Reflector, 22 December 2009, http://kanere.org/2009/12/22/ world-food-program-kicks-off-2nd-mix-me-nutritionalsupplement-survey/.

39 Jajj, "Social Technology and Refugee Encampment," 229.

40 Editorial Staff, "World Food Programme Kicks Off."

41 Micronutrient Powder (MixMe) Use.

42 Evelina Rok, "My Future Is so Bright I Need Sunglasses," blog, 10 July 2009.

43 Giorgio Agamben, Homo Sacer: Sovereign Power and Bare Life, trans. Daniel Heller-Roazen (Redwood City, CA: Stanford University Press, 1995), 133.

44 Agier, "Managing the Undesirables," 17.

45 Ibid.

46 Verdirame and Harrell-Bond, Rights in Exile, 298.

47 Ibid., 299. The authors reference a 1999 protection report for Kenya that included a long list of enrichment activities offered at Kakuma that sounded more "like a brochure for a summer camp" than a report about refugee children, that included the Sudanese walking boys, "one of the most deprived, traumatized, and malnourished groups of adolescents in the world" (300). They also reference in an endnote a 1994 UNICEF report, Children of War: Wandering Alone in Southern 
Sudan, which claimed that the thousands of Sudanese unaccompanied minors could resume normalcy upon arriving at Kakuma (328n51).

48 Qaabata Boru, "World Refugee Day: Kakuma at a Glance," Kanere News Reflector, 28 August 2013, http:// kanere.org/2013/o8/28/world-refugee-day-kakumaat-a-glance/. Also "World Refugee Day," Kanere News Reflector, 23 July 2012, http://kanere.org/2012/07/23/worldrefugee-day/; and "World Refugee Day," Kanere News Reflector, 16 August 2014, http://kanere.org/2014/o8/16/ world-refugee-day-2014/.

49 Editorial Staff, "Community Talking Point: World Refugee Day," Kakuma News Reflector, 23 July 2012, http://kanere.org/2012/07/23/ community-talking-point-world-refugee-day/.

50 Email correspondence, 15 April 2013.

51 KANERE's experience was consistent with the findings of Verdirame and Harrell-Bond, who observed that the UNHCR had a record of mounting obstacles to refugee associations, and to researchers or external reporters who might write negatively about their work. Rights in Exile, 198-200.

52 Bethany Ojalheto, "Refugee Free Press Struggling to Remain Afloat and Independent," Society for International Development, 1 October 2009, http://www.sidint. net/content/refugee-free-press-struggling-remain-afloatand-independent.

53 Ibid.

54 McGregor, "Keeping the News Alive."

55 Editorial Staff, "Refugee Free Press at Crossroads," Pambazuka News, 7 July 2009, http://www.pambazuka.net/en/ category.php/refugees/57613.

56 Qaabata Boru, "KAnere Refugee Free Press Editor Assaulted," Pambazuka News, 3 December 2009, http:// www.pambazuka.net/en/category.php/letters/60698.
57 Bethany Ohalheto, "Refugee News Reporting Project under Threat," Pambazuka News, 18 March 2010, http:// pambazuka.org/en/category/features/63143.

58 Ibid.

59 Qaabata Boru, "Freedom of the Press," McGill Daily, 3 November 2009, http://www.mcgilldaily.com/2009/11/ freedom_of_the_press/.

60 Ekuru Aukot, "Who Believes in the Rights of Immigrants? Do Refugees Have the Right to a Free Press?" Kakuma News Reflector 1, no. 3 (February 2009), https://kanere. org/2009/02/28/who-believes-in-the-rights-of-immigrants-do-refugees-in-kenya-have-the-right-to-a-freepress/.

61 Email communication, 13 May 2013.

62 Qaabata Boru, "New NGo Run-Newsletter Enhances News Access in Kakuma," Kakuma News Reflector, 18 August 2013, http://kanere.org/2013/o8/28/new-ngo-run-newsletter-enhances-news-access-in-kakuma-2/.

63 "Kakuman Refugee Newsletter," Humanitarian Futures Programme, February 2009, https://humanitarianfutures. wordpress.com/2009/02/o2/kakuma-refugee-newsletter/.

64 See crowdsource campaign, "KANERE Refugee Free Press,” Generosity, https://www.generosity.com/ fundraising/kanere-refugee-free-press.

65 Editorial, "Kanere: A Refugee-Run Free Press in Kenya," Kakuma News Reflector, August 2012, http://www.fmreview.org/en/young-and-out-of-place/kanere.pdf.

66 Sharon Welch, 2000. A Feminist Ethic of Risk (Minneapolis: Fortress, 2000).

67 Ibid., 155. 